\title{
Agricultural Prices in Pakistan: A Multimarket Analysis
}

\author{
FAIZ Mohammad and SAYYID T AHIR*
}

This paper attempts to analyse the effects of changes in agricultural prices on different segments of the society. Taking the cases of two major crops; namely wheat and rice, and of agricultural inputs in general, it works out the 'own-price effects' and 'cross-price effects' of price changes on producers, consumers, and the government in Pakistan. ${ }^{1}$ In this way the paper provides a broad (multimarket) framework which could be used to evaluate the government's agricultural price policy. ${ }^{2}$

The paper is divided into three sections. Section I discusses the methodological framework. The empirical analysis is provided in Section II. Section III deals with some tentative conclusions inferable from this study.

\section{METHODOLOGICAL FRAMEWORK}

\section{Assumptions $^{3}$}

The following assumptions have been made about the agricultural marketing arrangements in the country to keep the analysis within manageable limits.

(1) Procurement prices of wheat, cotton, and rice are in general less than those prevailing in the domestic (open) and international markets.

(2) The government releases its wheat stock to the open market through mills at prices slightly higher than the procurement price but bears most of the handling charges. Rice and cotton are procured mainly for export purposes. Their local

*The authors are respectively, Associate Professor and Professor of Economics at International Institute of Islamic Economics, Islamabad.

'Own price effects' (OPE) represent changes in the supply of and demand tor a commodity in response to the changes (made) in its price. 'Cross-price effects' (CPE), on the other hand, are similar changes in supply of and demand for other commodities than the one whose price is changed.

${ }^{2}$ See Thobani (1979) for somewhat limited treatment of this problem. See Braverman (1984) for justification of using a multimarket framework for studying changes in agricultural prices.

${ }^{3}$ See Mohammad and Tahir (1989) for necessary details of these assumptions. 
consumption is not subsidised. If the total stocks are not exhausted in a year, they become part of the buffer stock.

(3) Most of the agricultural inputs are subsidised either directly or indirectly. ${ }^{4}$

(4) Farmers keep a portion of their production for domestic consumption and sell the rest to the open market or the government. The proportion retained by them for domestic consumption remains unchanged despite changes in procurement prices and input subsidies. Consequently, an increase in procurement price or input subsidy leads to an increase in marketable surplus and vice versa.

(5) Prices of inputs are administratively controlled.

(6) Since most of the inputs are not good substitutes, cross-price effects of changes in their prices are ignored. The effects of inputs, which are complementary, are reflected in changes in cropped area and yield and hence in the supply of a commodity.

(7) Open markets are perfectly competitive. Accordingly, any change in supply and demand will fully reflect itself in the equilibrium price. Official prices are however, changed by administrative decisions. [This is basically a simplifying assumption. With some modifications the element of imperfections in the market can be accommodated in this model].

\section{THEORETICAL FRAMEWORK}

The paper uses traditional supply-and-demand-curves to calculate the gains and losses to different economic agents in the society in terms of consumer's surplus or producer's surplus. Wherever possible, direct estimates of revenue changes have also been worked out.

A brief description of the methods used is given below. ${ }^{5}$

\section{Effect of an Increase in Procurement Price ( $\Delta \mathrm{PP})$ on Producer}

Own Price Effect: Using supply-of-marketable-surplus curve (SS) in Figure 1, we note that $O P E$ of $\triangle P P$ is equal to area $2+3$. This area can be measured as:

$$
\Delta P S=Q_{1} P P+1 / 2 \Delta P P \Delta Q
$$

where $\Delta Q=e^{s} \frac{\Delta P P}{P P} \cdot Q_{1}$

(by definition of the elasticity of supply with respect to output price $e_{i}^{s}$ )

\footnotetext{
${ }^{4}$ This is a debatable assumption. However, we use it to simplify our analysis.

${ }^{5}$ See Mohammad and Tahir (1989) for details.
}

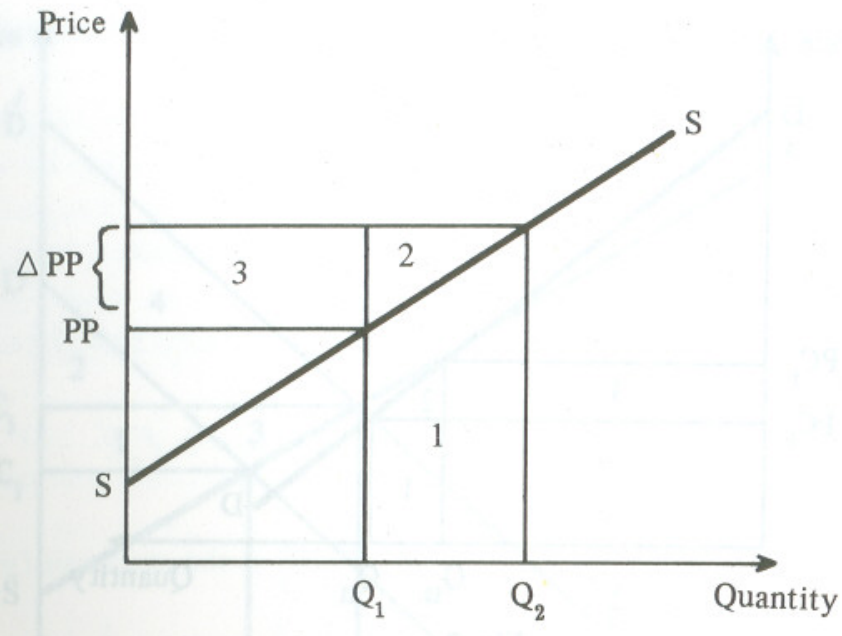

Fig. 1.

Cross-price Effects: These effects are in the form of changes in the production of other commodities when the $P P$ of a given commodity changes. They can be worked out by keeping the price of other commodities constant and shifting their supply curves to the left or right, depending on the nature of inter-crops relationships. They can be expressed as: ${ }^{6}$

$$
\Delta P S_{j}=\frac{1}{2 e_{j}^{s}}\left[Q_{j 2}^{2}-Q_{j 1}^{2}\right] \frac{P P_{j}}{Q_{j 1}}
$$

where $Q_{j 2}$ is determined by using the formula for 'cross-price elasticity of supply' for the $i$ th and $j$ th commodities; and $e_{j}^{s}$ is the own price elasticity of supply of $j$ th commodity.

\section{Effect of an Increase in Procurement Price Accompanied by \\ an Increase in Consumer Price on the Consumer}

Own-price Effect: Increase in the government's issue price $\left(P_{g}\right)$ is most certainly passed on to the consumer by mill-owners and other marketing channels through which the government's stocks are brought in to the market. This means an increase in the average price faced by the consumer. As a result, other things being equal, consumer surplus $(C S)$ would decline by area $2+3$ in Figure 2 . This change in $C S$ can be measured as 


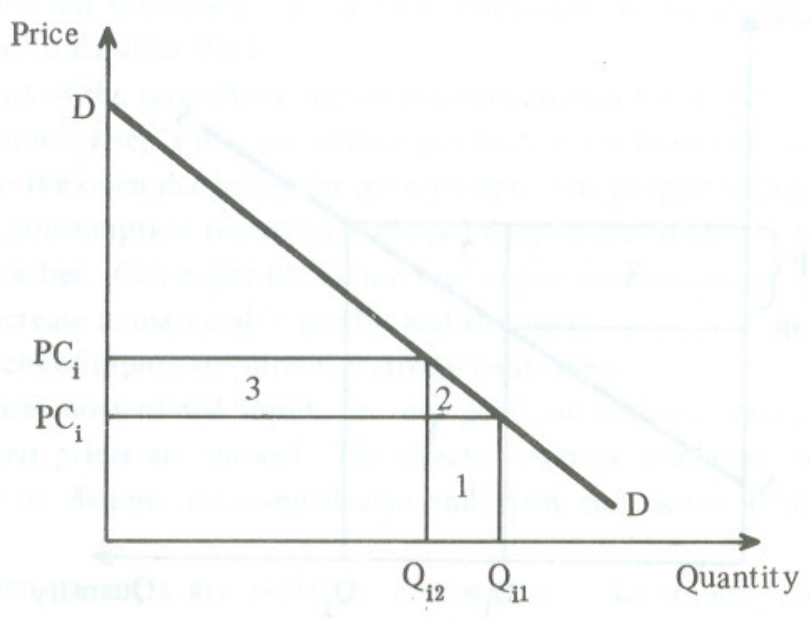

Fig. 2.

$\Delta C S_{i}=\Delta P C_{i} Q_{i 2}+1 / 2 \Delta P C_{i} \Delta Q_{i}$

where $\Delta Q_{i}={ }_{i}^{d} \frac{\Delta P C_{i}}{P C_{i}} \cdot Q_{i 1}$

(by definition of the elasticity of demand, $e_{i}^{d}$ )

Cross-price Effects: These effects are in the form of changes in quantitative demand for and prices of other commodities as a result of the increased price of the $i$ th commodity.

In Figure 3, a rightward shift in the demand curve for the $j$ th (substitute) good indicates both loss and gain to the consumer. The net gain can be measured with the help of Expression 4.

$$
\Delta C S_{j}=\frac{1}{2 e_{j}^{d}}\left[Q_{j 2}^{2}-Q_{j 1}^{2}\right] \frac{P C_{j}}{Q_{j 1}}
$$

where $\Delta Q_{j}=\left(Q_{j 2}-Q_{j 1}\right)=e_{j i}^{d} \frac{\Delta P C_{i}}{P C_{i}} Q_{j 1}$

(by definition of $e_{j i}^{d}$ ) and $P C_{j}$ is the price paid by the consumer for $j$ th good.

\section{Effect on Government Revenue}

As a result of an increased $P P$ and $P_{g}$, the government revenue may change for the following reasons:

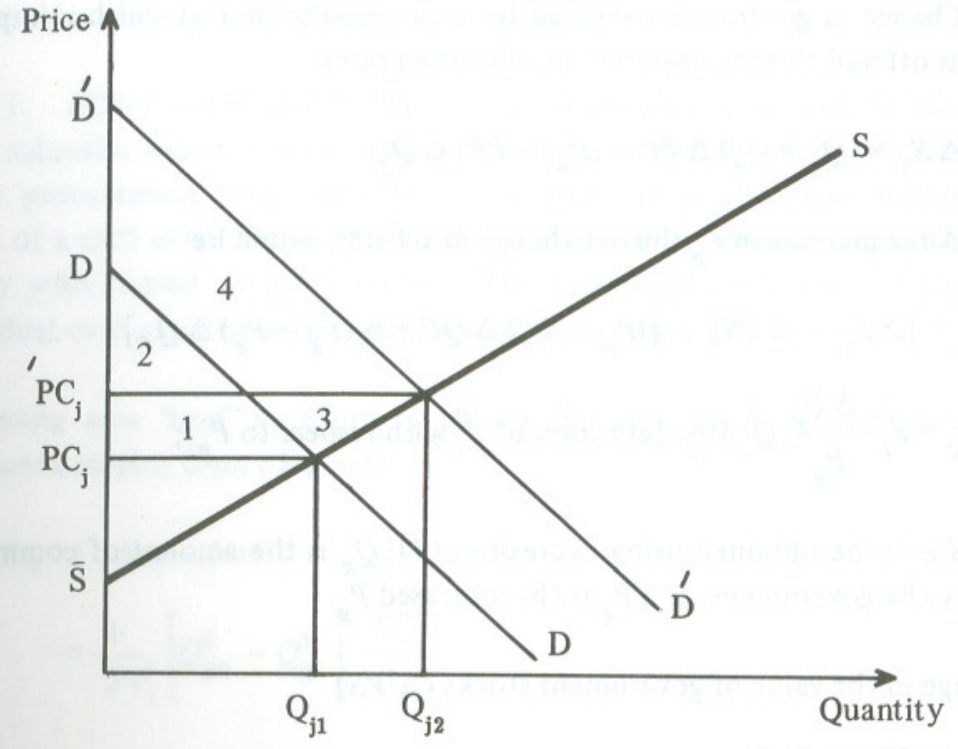

Fig. 3.

(a) Owing to an increased availability of marketable surplus the need to import a commodity such as wheat may become less than before. Reduction in imports of wheat would reduce the amount of subsidy $p$ and to the consumer, as the import price $(p w)$ of wheat has been generally more than its procurement prices. An increased issue price would also reduce consumption and, therefore, the subsidy paid to the consumer.

(b) If an announcement to increase $P P$ is accompanied by an increase in $P_{g}$ then the government will gain through the enhanced value of its existing stock as new $P P$ can be effective only in the next crop season.

(c) An increase in $P_{g}$ may, however, increase the government's budgetary allocation for wage indexation as it is likely to increase the cost of living.

(d) An increase in $P C_{i}$, by increasing the demand for substitutes, may result in less availability of those goods for export purposes. If exports are profitable, then this would reduce government revenue from its exports.

(e) An increase in $P P$ of exportable items such as rice and cotton, could reduce the profit from their exports (or increase the losses if the government is already making losses from their exports).

Only some of the less obvious measures to capture the above-stated changes in the government revenue are elaborated below. 
1. Change in government subsidy for a commodity part of which is imported and which is offered to the consumer on subsidised rates

(a) $\Delta S_{1}=\left(Q_{g}+Q_{g}\right) \Delta P P-\left(P_{w}-P P\right) \Delta Q_{g} \quad \ldots \quad \ldots$

(b) After increase in $P_{g}$ the net change in subsidy would be

$$
\Delta S_{2}=\left[\Delta S_{1}-\Delta C S\right]-\left[\left(P_{w}-\dot{P}_{g}\right) \Delta Q C+1 / 2\left(\dot{P}_{g}-P_{g}\right) \Delta Q_{C}\right] \quad \ldots
$$

where $\Delta Q_{c}=e_{i}^{d} \frac{\Delta P_{g}}{P_{g}} Q_{c}$ (by definition of $e_{i}^{d}$ with respect to $P_{g}$ );

$\triangle C S$ is to be obtained using expression (3); $Q_{g}$ is the amount of commodity procured by the government; and $\dot{P}_{g}$ is the increased $P_{g}$.

2. Change in the value of government stocks $(\Delta V S)$

$$
\Delta V S=\Delta P_{g} S_{t}
$$

where $\Delta P_{g}=$ change in issue price and ' $S_{t}$ ' is the stock of a commodity held by the government.

3. Increase in the cost of indexation will be worked out by first calculating the effect of an increase in the issue price on the cost of living index, and then applying the same rate of indexation as applied by the government in the 1987-88 budget.

Other effects on government revenue were calculated by using simple arithmetic. In most cases, first the effect of a change in $P P$ or $P_{g}$ is worked out on the quantity of a given commodity, and then the relevant conversion factor (price, tax rate or exchange rate) is used to get the figures in rupee terms.

Calculations relating to different types of effects of price changes described above have been done for only two commodities; namely wheat and rice. This was done primarily to keep the paper within manageable limits but also because these two commodities have experienced most frequent changes in their 'procurement and issue prices' (Government of Pakistan 1987-88).

\section{Increased Subsidies on Agricultural Input(s)}

Changing subsidies on inputs is another policy which the government may use to increase efficiency and income. In Pakistan this has been used in combination with changes in procurement prices. In this paper we try to evaluate this policy option as an al ternative to changes in procurement prices.

1. Effect on Producer: The effect on producer's income of an increase in input subsidies comes from a rightward shift in the supply curves of different goods where procurement prices (not the open market prices) remain unchanged. The effect of a shift in the supply curve can be estimated by using 'own-price elasticity of supply with respect to input prices'. The net effect on farmer's income from an individual crop could be estimated through expression $\left(8^{\prime}\right)^{7}$

(Assuming area 'bcef' in Figure 4 offsets the area 'PfeP' the net increase in the producer's surplus from $i$ th good)

$$
\begin{aligned}
P s_{i} & =\text { Area ' } a b c d \text { ' } \\
& =\frac{1}{2 e_{i}^{s}}\left[Q_{g 2}^{2}-Q_{g 1}^{2}\right] \frac{P P}{Q_{g 1}}
\end{aligned}
$$

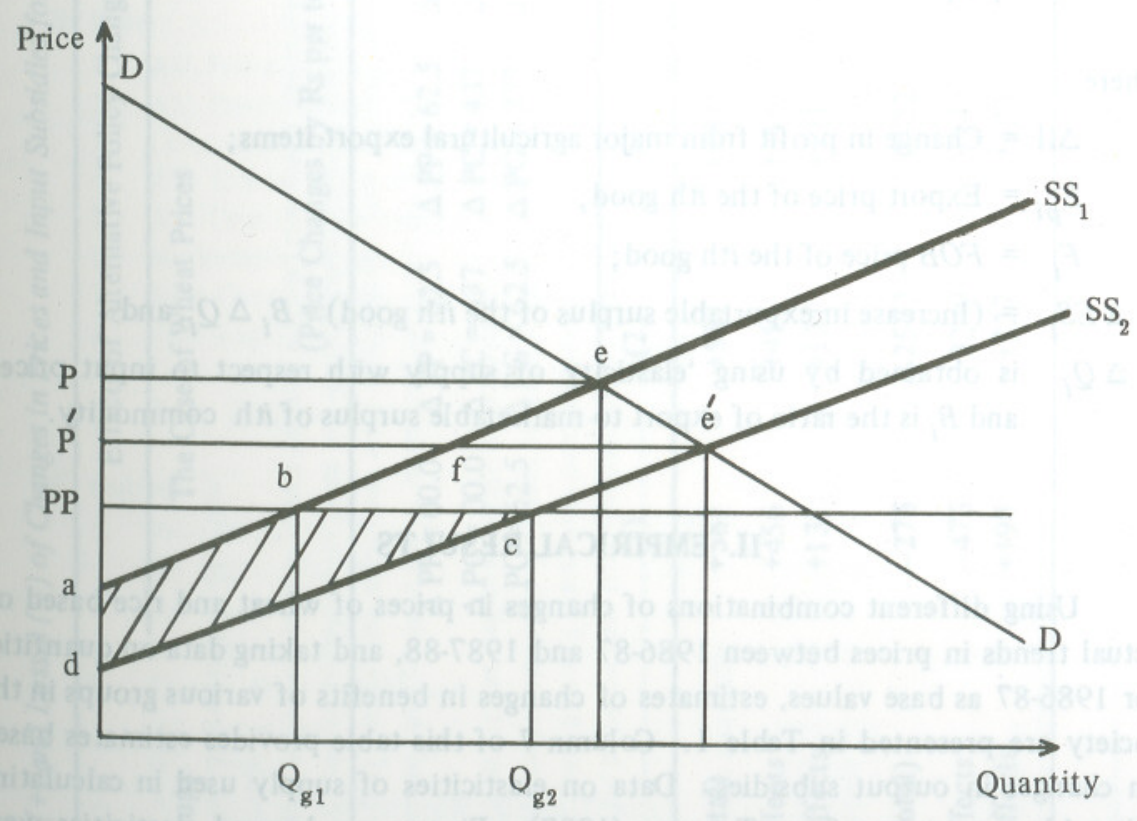

Fig. 4. 
where $Q_{g_{2}}$ is to be found using elasticity of supply with respect to input prices, $\left(e_{i k}^{s}\right)$

2. Effect on Consumer: An increase in input subsidies through increased supplies of different commodities could result in decreased consumer prices. The benefits to the consumer can be worked out by using Equation (3) where $Q_{i}$ is known and $P C_{i}$ is obtained using the 'own-price elasticity of demand' formula.

3. Effect on Government Revenue: An obvious effect of increased inputsubsidies would be to inflate the government bill on production subsidies. However, an increase in production is likely to decrease consumption subsidies as the government might have to import less to meet domestic foodgrain requirements. Similarly, the government could benefit from an increased supply of exportables and from the tax revenue or additional exports made possible by enhanced domestic production. Equation (9) elaborates the effect on the profit earned by government from an increased supply of exports. ${ }^{8}$

$$
\Delta \Pi=\sum_{i=1}^{n}\left(E P_{i}-F_{i}\right) \Delta E S_{i}
$$

where

$\Delta \Pi=$ Change in profit from major agricultural export items;

$E_{p i}=$ Export price of the $i$ th good;

$F_{i}=F O B$ price of the $i$ th good;

$\Delta E S_{i}=$ (Increase in exportable surplus of the $i$ th good $)=B_{i} \Delta Q_{i}$; and

$\Delta Q_{i}$ is obtained by using 'elasticity of supply with respect to input prices' and $B_{i}$ is the ratio of export to marketable surplus of $i$ th commodity.

\section{EMPIRICAL RESULTS}

Using different combinations of changes in prices of wheat and rice based on actual trends in prices between 1986-87 and 1987-88, and taking data on quantities for 1986-87 as base values, estimates of changes in benefits of various groups in the society are presented in Table 1 . Column 7 of this table provides estimates based on changes in output subsidies. Data on elasticities of supply used in calculating this table were taken from Tweeten (1987). Figures on demand elasticities were however assumed in the light of different studies carried out for Pakistan Alderman

${ }^{8}$ Calculation of other effects on government revenue requires simple arithmetic and is therefore not explained here. The interested reader may see Mohammad and Tahir (1989).

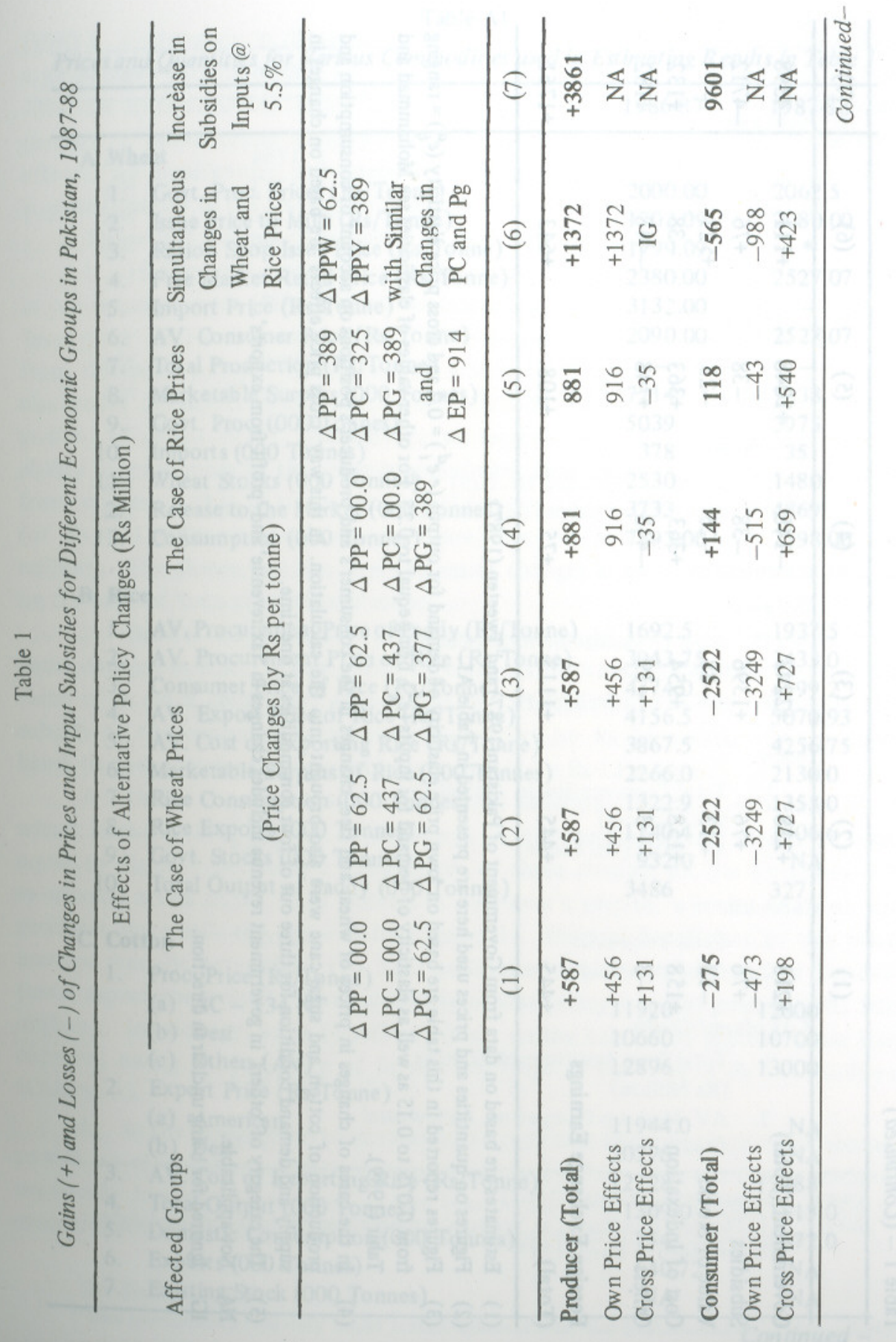




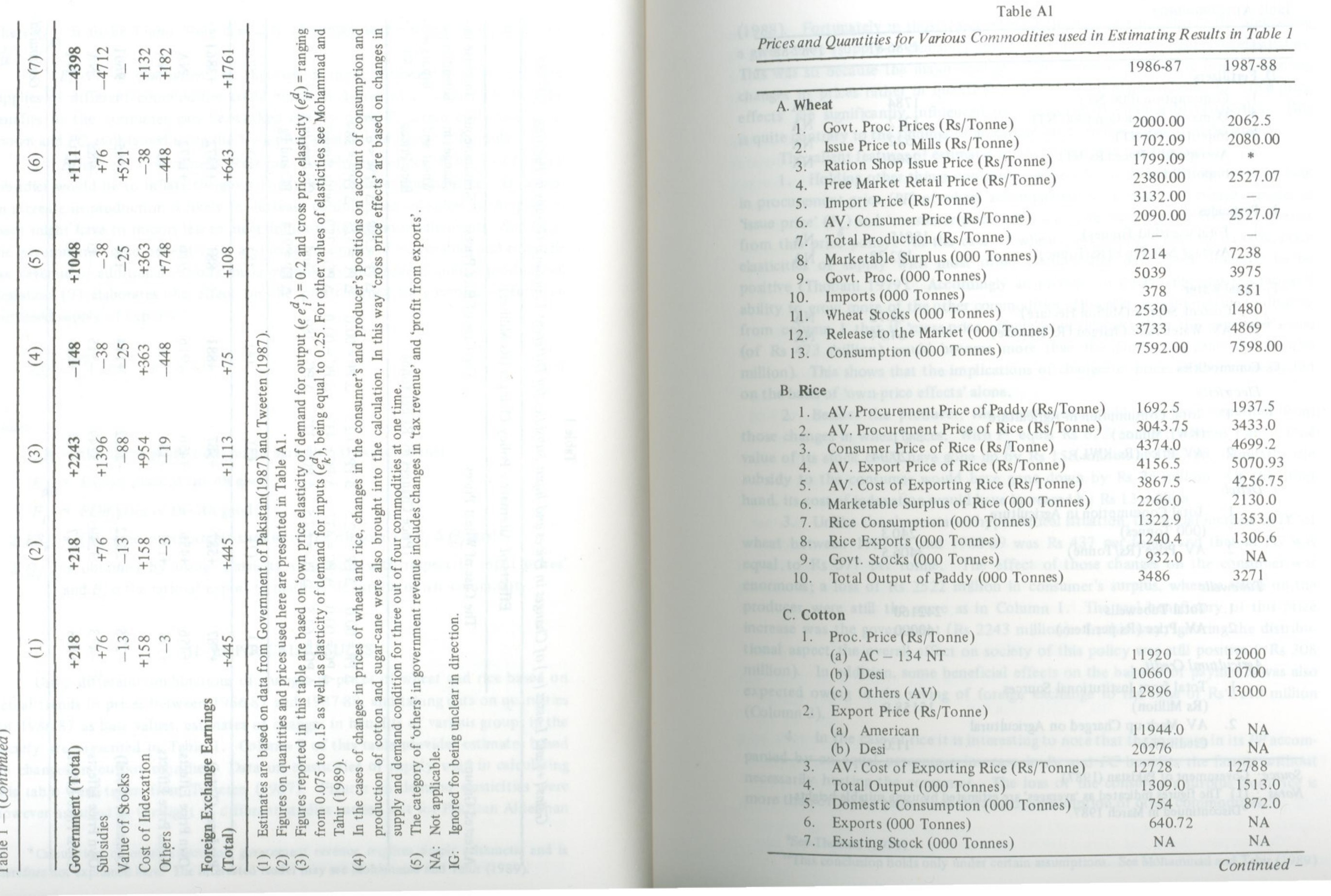


1986-87

\section{Fertilizers}

1. Consumption (000 NT)

2. Domestic Production (000 NT)

3. Imports (000 NT)

4. Average Sale Price (Rs NT)

5. Import Price

\section{E. Pesticides}

1. Total use (000 Tonnes)

2. Average Sale Price (Rs Tonne)

15815

102.38

\section{F. Canal Water}

2. AV. Water Rate Charged (Rs Hectare)

12.12 NA

$64.94 \quad$ NA

\section{G. Commodities}

Electricity

1. Total Consumption in Agriculture

2. AV. Price (Rs/KWL)

Deisel

1. Total Consumption in Agriculture (000 Tonnes)

2. AV. Price (Rs/Tonne)

Tubewells

1. Total Tubewells

2. AV. Price (Rs per Item)

\section{Agricultural Credit}

1. Total from Institutional Sources (Rs Million)

2. AV. Mark-up Charged on Agricultural Credit (\%)
1. Current Supply (Million Hectare)

(KWL Million)
NA

NA

NA

NA

NA

NA

NA
(1988). Fortunately in those cases where estimates were to capture the area along a given curve (supply or demand) results were not sensitive to figures on elasticities. This was so because the major change in the revenue curve came from exogenous changes in prices rather in quantities. However, estimates relating to "cross-price effects' are significantly influenced by changes in the values of elasticities. This is quite contrary to the findings of an earlier study on the subject for Pakistan. ${ }^{9}$.

The salient features of estimates in Table 1 are discussed below.

1. Holding other things constant, the benefits to the producer of an increase in procurement price $(P P)$ of wheat accompanied by an equal percentage increase in 'issue price' $\left(P_{g}\right)$ and 'consumer price' $(P C)$ are more than the loss to the consumer from this price policy. In the case of wheat, this happens because its cross-price elasticities of supply with most other commodities have been observed to be positive (Thobani 1979). Accordingly an increase in its $P P$ enhances the farmer's ability to grow more of the other commodities. However, it is interesting to observe from column 1 that if 'cross-price effects' were ignored then the consumer's loss (of Rs 473 million) would become more than the producer's gains (of Rs 456 million). This shows that the implications of changes in prices cannot be evaluated on the basis of 'own-price effects' alone.

2. Besides the producer, the government could also have benefited from those changes in wheat prices. With $P_{g}$ equal Rs 62.5 tonne (Columns 1 and 2) the value of its stock could have gone up by Rs 158 million in 1987-88. Similarly, the subsidy to the consumer would have gone down by Rs 76 million. On the other hand, its cost of indexation would have increased by Rs 13 million.

3. Unlike the above-stated hypothetical situation, the actual increase in $P C$ of wheat between $1987-88$ and $1988-89$ was Rs 437 per tonne and that in $P G$ was equal to Rs 377 per tonne. The effect of those changes on the consumer was enormous; a loss of Rs 2522 million in consumer's surplus, whereas those on the producer were still the same as in Column 1. The real beneficiary of this price increase was the government (Rs 2243 million). In this way, ignoring the distributional aspect the overall effect on society of this policy was still positive (=Rs 308 million). In addition, some beneficial effects on the balance of payments was also expected owing to the saving of foreign exchange to the tune of Rs 1113 million (Column 3).

4. In the case of rice it is interesting to note that the increase in its $P P$ accompanied by an equal percentage increase in $P g$ and $P C$ benefits the farmer without necessarily hurting the consumer. The loss of the consumer's surplus from rice is more than offset by gains from enhanced consumption of other commodities. ${ }^{10}$

${ }^{9}$ See Thobani (1979).

${ }^{10}$ This conclusion holds only under certain assumptions. See Mohammad and Tahir (1989)

Source: Government of Pakistan (1987)
Notes : (1) The figures indicated as 'averages' are estimated by using suitable heights *Discontinued in March 1987 
5. In our calculations when $P P$ of rice is increased without taking into account the increase in the export price of rice, then the government becomes a loser. However, if the actual rise in export prices of rice (= Rs 914 per tonne between 1986-87 and 1987-88) is taken into account the government gains from this policy, to the extent of Rs 1048 million. (Column 5).

6. As a result of a simultaneous increase in $P P, P C$ and $P g$ of wheat and rice, most of the conclusions stated above are reinforced. This can be seen from estimates in Column 6, where 'cross-price effects' on the producer have been ignored for being unclear in their direction. Accordingly if we take the most simple cases of price changes from Columns 1 and 4 , (and put them in Column 6) we observe the producer to be gaining much more than the loss to the consumer (Rs 1322 million as opposed to Rs 565 million). On the other hand, even if one ignores the increase in export prices of rice in 1987-88, the government would still benefit to the tune of Rs 111 million as a result of a simultaneous increase in $P P$ and $P g$ of wheat and rice. The favourable effect of Rs 643 on the balance of payments might have been the additional benefit of those policies.

7. Column 7 presents estimates based on a 5.5 percent increase in subsidies in all major agricultural inputs. This increase in the rate of subsidies is equal to the weighted average increase in procurement prices of wheat and rice in 1987-88 analysed in Columns 1 to 6 . Comparing the two policy options, one finds the benefits of an increase in input subsidies (IS policy) on the producer and the consumer to be much more than those of a similar increase in $P P$ and $P C$ ( $P P$ policy). From $I S$ policy the producer benefits to the tune of Rs 3861 million (as compared to Rs 1372 million from PP policy). On the other hand, the consumer is a net gainer to the extent of Rs 9601 million from the $I S$ policy whereas it is a net loser of Rs 565 million from $P P$ policy. The major loser from the $I S$ policy is the government. It has to forego Rs 4397 million if it adopts the $I S$ policy. On the other hand, it could gain Rs 643 million from the $P P$ policy even by a very conservative estimate.

In terms of absolute gains to the society the $I S$ policy therefore appears superior to the $P P$ policy. ${ }^{11}$

\section{CONCLUSIONS}

Besides emphasising the importance of using a multimarket framework to evaluate pricing policy options, the paper has two main conclusions to offer.

First, although the increase in $P P$ accompanied by an equal percentage increase in $P g$ and $P C$ for wheat and rice (in dividually and collectively) benefits the producer

"This supports Barker and Hayami (1976) and Chaudhry (1984). However we have something to add to it for which please see Section III. and the government more than the loss to the consumer, it could become a desirable policy option for the society only if income redistribution from the latter to the former groups is considered very desirable. Otherwise in spite of efficiency gains this may not be socially desirable policy option.

Second the $I S$ policy, as opposed to the $P P$ policy, appears to be more beneficial to the society only if one ignores its effects on the government revenue However, a country like Pakistan with serious financial constraints is more likely to favour the $P P$ policy for two reasons:

(a) Contrary to the $I S$ policy, an increase in procurement prices, besides benefiting the producer raises revenue for the government by enhancing the value of its stocks and by allowing more foreign exchange earnings This, in a way, has established a vested interest of the government in this policy action; and

(b) The IS policy, as opposed to $P P$ policy, affects the government budget directly and on this account has to compete with other heads of expenditure in terms of its social valuation. Due to difficult financial conditions in Pakistan in the last few years it seems that not only the social marginal values of the competing public activities have gone up but also public revenue in general has become more valuable than the money going to other segments of the society. In this situation, the argument in favour of the $I S$ policy as opposed to $P P$ policy on the basis of their current monetary benefits may not carry much weight.

However the fact that a small increase in input subsidies could provide substantial welfare gains should not be underestimated if one is exploring avenues to promote agricultural development.

\section{REFERENCES}

Alderman, H. (1988). "Estimates of Consumer Price Response in Pakistan using Market Price Data". Pakistan Development Review. Vol. XXVII, No. 2. pp. 89-108.

Barker, R., and Y. Hayami (1976). "Price Support Versus Input Subsidy for Food Self-sufficiency in Developing Countries". American Journal of Agricultural Economics. November. pp. 617-628.

Braverman, A., et al. (1984). "An Economic Analysis of Reducing Input Subsidies to the Livestock Sector in Cyprus". CPD Discussion Paper No. 1984-8. Washing. ton D.C.: World Bank. 
Braverman, A., et al. (1984). "Multi-Market Analysis of Agricultural Pricing Policies in Korea". In D. Newbery and N. Stern (eds.), The Theory of Taxation for Developing Coun tries.

Chaudhry, M. G. (1984). "Autarky in Food: Evidence and Prospects". Pakistan Development Review. Vol. XXII, Nos. 2 \& 3. pp. 257-272.

Mohammad, Faiz, and Syed Tahir (1989). "Agricultural Markets in Pakistan: A Multimarket Analysis”. Pakistan Development Review. Vol. XXVII, No. 4.

Pakistan, Government of (n.d.). System of Price Support and Procurement of Selected Agricultural Commodities in Pakistan. Islamabad: Ministry of Food and Agriculture, Agricultural Prices Commission (APCOM).

Pakistan, Government of (1987). Economic Survey 1987-88. Islamabad: Finance Division, Economic Adviser's Wing.

Thobani, Mateen (1979). "The Effect of a Change in Wheat Prices on Incomes", Pakistan Development Review. Vol. XVIII, No. 4. pp. 283-312.

Tweeten, Luther (1987). Supply Response in Pakistan Agriculture: A System Approach. APCOM Series No. 58. Islamabad: Agricultural Prices Commission.

\section{Comments on \\ "Agricultural Prices in Pakistan: \\ A Multimarket Analysis"}

This work on the implications of agricultural prices follows Brown, and Cheong and D. Silva's work on Pakistan (Brown 1980). This preceeding work has calculated producer's gain, consumer's gain, and the government's gain, given the agrarian price structure over the last two decades. This analysis has been disaggregated to crop level. Faiż and Tahir have repeated this exercise. So the most important general implications of this analysis are already well known.

1. An increase in domestic crop prices for wheat and rice will result in:

a. Producer's gain;

b. Consumer's loss

c. Government's gain through revenue; and

d. Manufacturing's loss through need to raise money wages. Price increases for other crops also lead to manufacturing's loss due to higher input prices and reduced competitiveness. If Faiz and Tahir are doing a general equilibrium analysis they need to take this point into account.

2. An increase in input subsidies for various crops will result in:

a. Producer's gain;

b. Consumer's gain;

c. Government's internal budget deficit. But government's gain from an increase in export revenue; and

d. Manufacturing's gain through low real wages. Again Faiz and Tahir need to take this into account.

So price policy leads to an increase in productive efficiency in agriculture. However it's distribution effect can be negative with consumer's loss outweighing producer's gain.

Input subsidy policy leads to an increase in output and profitability in agriculture. It can also increase productive efficiency if the increase in output is greater than the subsidy. And the distribution effect of input subsidies is also positive. 
However the state can make a loss if it's internal deficit is greater than it's export gains.

There is a need for positive effects in both productivity and distribution. And government's gain is also desirable. This means that neither price policy, nor input subsidy policy is desirable on it's own. Both policies have to be combined together in some mix.

This is an important corollary to remember these days when the IMF's structural adjustment programme is being applied in Pakistan. The structural adjustment programme has only one priority, which is reduction in the government's budget deficit. Therefore it recommends price policy and removal of input subsidies. Consumers suffer while producers and the government gains. However state policy has to be slightly more welfare oriented than the IMF's policy if it is to survive.

Moazam Mahmood

Pakistan Institute of

Development Economics,

Islamabad

\section{REFERENCE}

Brown, G. (1980). K. Cheong, and E. H. D’Silva, (1984). Prices, Terms of Trade and the Role of the Government in Pakistan's Agriculture. World Bank Staff Working Paper, No. 643. 